JURNAL NALAR PENDIDIKAN

ISSN [E]: 2477-0515 ISSN [P]: 2339-0794

DOI: $10.26858 /$ jnp.v9i1.18172

Online: https://ojs.unm.ac.id/nalar

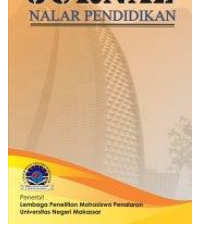

\title{
KORELASI ANTARA KECERDASAN EMOSIONAL, KECERDASAN SOSIAL, DAN KEMAMPUAN AWAL TERHADAP PRESTASI BELAJAR MATEMATIKA SISWA KELAS VIII SMP NEGERI 1 SUNGGUMINASA
}

\author{
St. Aflahah \\ Balai Penelitian dan Pengembangan Agama Makassar \\ siti.aflahah@gmail.com
}

\begin{abstract}
Abstrak
Penelitian ini bertujuan untuk mengetahui pengaruh kecerdasan emosional, kecerdasan sosial, dan kemampuan awal matematika secara bersamaan pada prestasi hasil belajar matematika siswa kelas VIII SMP Negeri 1 Sungguminasa. Penelitian ini menggunakan pendekatan metode kuantitatif melalui penggunaan jenis penelitian ex post facto. Penelitian ini mengambil dua kelas sebagai sampel penelitian sebanyak 70 siswa yakni kelas VIII B dan VIII C dipilih secara acak dengan menggunakan teknik simple random sampling dari seluruh kelas VIII pada tahun ajaran 2014-2015 yang berjumlah dua belas kelas. Instrumen pengumpulan data yang digunakan adalah kuesioner dan tes. Analisis data menggunakan statistik deskriptif dan statistik inferensial. Hasil analisis statistik inferensial menemukan bahwa kemampuan awal matematika, kecerdasan emosional, dan kecerdasan sosial siswa berpengaruh secara bersama-sama dan signifikan terhadap prestasi belajar matematika siswa dengan persamaan regresi berganda $\mathrm{Y}=-31,63+0.50 \mathrm{X}_{1}+0,11 \mathrm{X}_{2}+0,40 \mathrm{X}_{3}$. Berdasarkan hasil penelitian diatas, dapat disimpulkan bahwa dengan adanya upaya meningkatkan kecerdasan emosional, dan kecerdasan sosial, serta kemampuan awal siswa pada matematika dapat membantu mereka dalam meningkatkan prestasi belajar matematikanya.
\end{abstract}

Kata kunci: kecerdasan emosional, prestasi belajar matematika, kemampuan awal matematika, kecerdasan sosial

THE CORRELATION OF EMOTIONAL INTELLIGENCE, SOCIAL INTELLIGENCE, AND MATHEMATICS PRIOR KNOWLEDGE TOWARD MATHEMATICS LEARNING ACHIEVEMENT OF $8^{\text {TH }}$ GRADE STUDENTS IN SMP NEGERI 1 SUNGGUMINASA

\begin{abstract}
This study aims to determine the effect of emotional intelligence, social intelligence, and early mathematical ability simultaneously on the achievement of mathematics learning outcomes of eighth grade students of SMP Negeri 1 Sungguminasa. This study uses a quantitative method approach through the use of ex post facto research. This study took two classes as the research sample as many as 70 students namely class VIII B and VIII C selected randomly using simple random sampling technique from all class VIII in the 2014-2015 academic year which amounted to twelve classes. The data collection instruments used were questionnaires and tests. Data analysis used descriptive statistics and inferential statistics. The results of inferential statistical analysis found that students' initial mathematical ability, emotional intelligence, and social intelligence had a joint and significant effect on students' mathematics learning achievement with multiple regression equation $Y=-31.63+0.50 X 1+$ $0.11 X 2+0.40 X 3$. Based on the results of the research above, it can be concluded that efforts to improve emotional intelligence and social intelligence, as well as students' initial abilities in mathematics can help them improve their mathematics learning achievement.
\end{abstract}


Keywords: emotional intelligence, mathematics learning achievement, mathematics prior knowledge, social intelligence.

\section{PENDAHULUAN}

Pendidikan merupakan hal yang sangat krusial di Indonesia. Kualitas sumber daya manusia menjadi hal yang patut untuk ditingkatkan. Pada tahun 2011, kemerosotan terjadi pada nilai IPM atau Indeks Pembangunan Manusia yang terjun 16 posisi ke bawah menjadikan Indonesia berada pada posisi 124 dari 180 negara sesuai data yang didapatkan melalui The United Nations Development Programme (UNDP). Pada Tahun selanjutnya, data dari UNESCO memaparkan bahwa Indonesia menempati posisi 60 negara terendah dalam nilai Education Development Index (EDI) atau Indeks Pembangunan Pendidikan [1]. Terdapat berbagai faktor yang mempengaruhi rendahnya kualitas pendidikan di Indonesia, salah satunya kualitas peserta didik.

Banyak hal yang dapat dibenahi demi meningkatkan kualitas peserta didik. Prestasi belajar siswa menjadi hal yang penting dalam hal ini sebab prestasi belajar siswa mencerminkan kualitas peserta didik dan tenaga pendidik [2]. Prestasi belajar siswa menjadi objek penelitian yang sering dikaji oleh para peneliti sebab prestasi belajar sangat erat kaitannya dengan keterampilan siswa dalam menerapkan hasil belajar yang telah diperoleh melalui kehidupan keseharian [3]. Di Indonesia, prestasi belajar siswa didefinisikan sebagai kemampuan yang dimiliki oleh siswa yang merupakan hasil pengembangan melalui subjek pelajaran di sekolah, diuji dengan tes, dan dinilai dengan angka oleh guru [4].

Matematika memiliki peranan penting dalam memprediksi potensi siswa di sekolah, tetapi mayoritas siswa memiliki mindset bahwa matematika menjadi mata pelajaran yang sukar dipahami [5]. Suatu penguasaan kemampuan siswa sebelum diberikan perkembangan pengetahuan melalui proses belajar mengajar disebut kemampuan awal sehingga dapat menjadi patokan guru dalam memberikan pengajaran nantinya [6]. Kemampuan awal matematika siswa yang tidak memenuhi standar untuk memahami materi di tingkat yang lebih sulit menjadi salah satu penyebab hal tersebut [7]. Kemampuan awal memiliki lima prinsip utama dalam belajar yaitu subsumption, organizer, progressive differentiation, consolidation, dan integrative reconciliation [8]. Kemampuan ini dapat dikategorikan dalam kecerdasan intelektual. Namun, hasil penelitian para peneliti University of
Queensland dari ribuan anak di empat negara menemukan bahwa kecerdasan intelektual ini merupakan faktor genetik sebesar 20\% sampai $40 \%$ sehingga tidak semua siswa dilahirkan dengan kecerdasan intelektual yang tinggi [9].

Oleh sebab itu, guru yang memiliki sangat berperan dalam pembelajaran mengajar juga perlu memperhatikan terkait prestasi belajar matematika siswa bisa mempengaruhi kecerdasan lainnya. Kecerdasan intelektual cuma berkontribusi $20 \%$ terhadap kesuksesan individu [10]. Kecerdasan emosional dan kecerdasan sosial juga memiliki peran dalam keberhasilan seseorang [10].

Perkembangan ilmu pengetahuan yang begitu pesat membawa paradigma baru bahwa kecerdasan sosial juga perlu dikembangkan sebab erat kaitannya dengan keterampilan sikap sosial serta pilar interaktif Pendidikan Matematika sebagaimana diatur dalam Kurikulum 2013 [11]. Kecerdasan sosial meliputi bakat, kepekaan sosial, hubungan sosial, dan kemampuan mengendalikan emosi [12]. Kecerdasan emosional terdiri atas self-awareness atau kesadaran diri, pengendalian diri, motivation, dan empati [13].

Kecerdasan sosial adalah satu dari beberapa jenis kecerdasan yang dapat menopang keberhasilan seseorang. Kecerdasan sosial dapat didefinisikan sebagai kemampuan untuk berperilaku bijak dalam interaksi sosial [10]. Kecerdasan sosial terdiri atas kecerdasan sosial internal dan eksternal [14]. Komponen kecerdasan sosial yaitu keterampilan sosial dan fasilitas sosial [10]. Keterampilan sosial terdiri atas kesadaran sosial (social awareness), kehadiran (attendance), keaslian (genuineness), dan kejelasan (clarity), serta empati (empathy). Fasilitas sosial terdiri atas sinkronisasi, presentasi diri, pengaruh, dan kepedulian.

Berdasarkan beberapa pernyataan diatas, peneliti menetapkan tujuan yang diharapkan tercapai terhadap penelitian ini untuk mengetahui: (1) korelasi kecerdasan emosional, dan kecerdasan sosial, serta siswa untuk pelajaran matematika, (2) korelasi pada kecerdasan emosional dalam prestasi hasil belajar siswa terhadap matematika, (3) korelasi kecerdasan sosial pada tingkat prestasi hasil belajar siswa terhadap matematika, (4) korelasi kemampuan awal matematika dalam prestasi hasil belajar mata pelajaran matematika dari siswa. 


\section{METODE PENELITIAN}

Penelitian ini memakai pendekatan metode kuantitatif melalui penggunaan jenis penelitian $e x$ post facto, dimana penelitian dilaksanakan untuk meneliti korelasi antara kecerdasan emosional, dan sosial, serta kemampuan awal dalam pelajaran matematika melalui strategi sesuai prestasi hasil belajar matematika siswa secara bersamaan. Ex post facto digunakan sebab pada penelitian ini, kecerdasan emosional, dan sosial, serta kemampuan awal matematika, beserta hasil belajar matematika telah dimiliki oleh siswa atau merupakan peristiwa yang telah terjadi [15]. Kemudian akan diteliti faktorfaktor yang berkontribusi dalam kompetensi yang dipunyai dari siswa tersebut khususnya prestasi terhadap hasil belajar dalam mata pelajaran matematika. Sehingga penelitian ini bermaksud melakukan pengujian korelasi terhadap tiga variabel bebas yakni kecerdasan emosional $\left(\mathrm{X}_{1}\right)$, kecerdasan sosial $\left(\mathrm{X}_{2}\right)$, serta kemampuan awal matematika $\left(\mathrm{X}_{3}\right)$ dengan prestasi hasil belajar matematika (Y).

Lokasi penelitian ini berada di SMP Negeri 1 Sungguminasa dengan mengambil sampel dua kelas secara acak pada siswa kelas VIII B serta VIII C Tahun Pelajaran 2014-2015 pada tiap kelas VIII yang berjumlah dua belas kelas. Teknik perolehan sampel terhadap penelitian yang dilakukan dengan memakai simple random sampling.

Instrumen perolehan data dipakai berupa kuesioner dantes. Kuesioner disusun melalui penggunaan skala Likert dalam mengukur kecerdasan emosional dan kecerdasan sosial siswa. Tes digunakan untuk mengukur skor kemampuan awal matematika serta prestasi hasil belajar yang diperoleh siswa di mata pelajaran matematika. Kemudian teknik terhadap penelitian ini dilakukan dengan teknik analisis data statistik deskriptif \& inferensial.

\section{HASIL DAN PEMBAHASAN \\ Hasil analisis statistik deskriptif}

Jumlah sampel pada penelitian yang dilakukan ialah 70 siswa. Skor maksimal untuk prestasi hasil belajar matematika ialah 100. Hasil dari perolehan data analisis statistik deskriptif memperoleh hasil uji prestasi hasil belajar dari mata pelajaran matematika yang diperoleh siswa di kelas VIII SMP Negeri 1 Sungguminasa pada Tahun Pelajaran 2014-2015 tergolong pada kategori rendah skor rerata sebesar 61,8 serta deviasi standar 15,71. Adapun distribusi frekuensi prestasi belajar tercantum melalui Tabel 1 berikut ini.

Tabel 1. Distribusi Frekuensi Prestasi Belajar Matematika

\begin{tabular}{cccc}
\hline Interval Nilai & Kategori & Frekuensi & Persentase \\
\hline $0-54$ & Sangat Rendah & 19 & 27 \\
$55-64$ & Rendah & 18 & 26 \\
$65-79$ & Sedang & 26 & 37 \\
$80-89$ & Tinggi & 6 & 9 \\
$90-100$ & Sangat Tinggi & 1 & 1 \\
\hline Jumlah & & 70 & 100 \\
\hline
\end{tabular}

Kecerdasan emosional dan kecerdasan sosial siswa memiliki beberapa indikator yang dijabarkan dalam item-item pernyataan dengan menggunakan skala Likert. Masing-masing item diberi skor 1-4. Kecerdasan emosional siswa terdiri dari 34 item dengan nilai minimal 34 (34 x 1) dan nilai maksimal 136 (34 x 4). Kecerdasan emosional siswa terdiri dari 33 item dengan nilai minimal $33(33 \times 1)$ dan nilai maksimal 132 (33 x 4).

Kecerdasan emosional siswa berada di tingkat kategori sangat tinggi terhadap skor rata-rata sebesar 109,5 dan deviasi standar 9,49. Adapun distribusi frekuensi kecerdasan emosional tersebut dapat dilihat

Tabel 2. Distribusi Frekuensi Kecerdasan Emosional pada Tabel 2. Kecerdasan sosial siswa $\left(\mathrm{X}_{2}\right)$ berada di tingkat kategori tinggi pada perolehan skor rerata mencapai 100,4 serta deviasi standar 9,49. Adapun distribusi frekuensi kecerdasan sosial tersebut tercantum dalam Tabel 3.

Variabel terakhir ialah kemampuan awal matematika $\left(\mathrm{X}_{3}\right)$ dengan skor maksimal 100. Kemampuan awal matematika siswa berada di tingkat skor rata-rata sedang sebesar 69,2 dan deviasi standar 18,76. Adapun distribusi frekuensi kemampuan awal matematika tersebut tercantum di Tabel 4. 


\begin{tabular}{cccc}
\hline Interval Nilai & Kategori & Frekuensi & Persentase \\
\hline$X \leq 95,265$ & Sangat Rendah & 6 & 8,5 \\
$95,265<X \leq 104,755$ & Rendah & 13 & 18,5 \\
$104,755<X \leq 114,245$ & Sedang & 28 & 40 \\
$114,245<X \leq 123,735$ & Tinggi & 19 & 27 \\
$X>123,735$ & Sangat Tinggi & 4 & 6 \\
\hline Jumlah & & 70 & 100 \\
\hline
\end{tabular}

Tabel 3. Distribusi Frekuensi Kecerdasan Sosial

\begin{tabular}{cccc}
\hline Interval Nilai & Kategori & Frekuensi & Persentase \\
\hline $\mathrm{X} \leq 86,165$ & Sangat Rendah & 6 & 8,5 \\
$86,165<\mathrm{X} \leq 95,655$ & Rendah & 18 & 25,5 \\
$95,655<\mathrm{X} \leq 105,145$ & Sedang & 23 & 33 \\
$105,145<\mathrm{X} \leq 114,635$ & Tinggi & 19 & 27 \\
$\mathrm{X}>114,635$ & Sangat Tinggi & 4 & 6 \\
\hline Jumlah & & 70 & 100 \\
\hline
\end{tabular}

Tabel 4. Distribusi frekuensi kemampuan awal matematika

\begin{tabular}{cccc}
\hline Interval Nilai & Kategori & Frekuensi & Persentase \\
\hline $0-54$ & Sangat Rendah & 11 & 16 \\
$55-64$ & Rendah & 11 & 16 \\
$65-79$ & Sedang & 18 & 26 \\
$80-89$ & Tinggi & 22 & 31 \\
$90-100$ & Sangat Tinggi & 8 & 11 \\
\hline Jumlah & & 70 & 100 \\
\hline
\end{tabular}

\section{Uji Asumsi Klasik}

\section{Uji Normalitas}

Pengujian normalitas dilakukan sebagai dasar untuk bisa memahami hasil perolehan data telah berdistribusi normal atau sebaliknya, KolmogorovSmirnov digunakan dalam uji analisis. Tabel 5 menunjukkan hasil perolehan dari data berupa statistik dengan menggunakan SPSS 21 untuk uji normalitas yaitu data variabel terikat prestasi belajar berdistribusi normal. Hal ini ditunjukkan oleh $p$ value variabel yaitu sebesar $0,26>\alpha=0,05$.

Tabel 5. Hasil Uji Normalitas Kolmogorov-Smirnov

\begin{tabular}{ccc}
\hline & & Prestasi Belajar \\
\hline$N$ & & 70 \\
Normal Parameters $^{a . b}$ & Mean & 61,8 \\
& Std. Deviation & 15,71 \\
& Absolute & 0,12 \\
& Positive & 0,06 \\
Kolmogorov-Smirnov $Z$ & Negative & $-0,12$ \\
Asymp. Sig. (2 tailed) & & 1,01 \\
& & 0,26 \\
\hline
\end{tabular}

\section{Uji Linearitas}

Uji linearitas dilakukan dengan tujuan agar diketahuinya setiap variabel bebas terbukti memperoleh korelasi linier atau tidaknya variabel terhadap variabel terikat secara signifikan, nilai signifikansi $\alpha$ yang dipilih yaitu 0,05 . Prasyarat yang perlu dipenuhi terhadap uji regresi ini ialah masing- masing variabel bebas yaitu kecerdasan emosional, dan kecerdasan sosial, serta kemampuan awal matematika mempunyai korelasi yang linear pada variabel terikat yakni prestasi hasil belajar mata pelajaran matematika. Hasil uji linearitas tercantum dalam Tabel 6 berikut ini. 
Berdasarkan perolehan dari uji linearitas melalui SPSS 21 yang tercantum di tabel 6 diperoleh $p$-value setiap variabel bebas lebih besar dari $\alpha=0,05$ yakni kecerdasan emosional sebesar $0,95>\alpha=0,05$; kecerdasan sosial sebesar $0,29>\alpha=0,05$; dan kemampuan awal matematika sebesar 0,24> $>=0,05$ sehingga bisa di ambil suatu kesimpulan bahwa setiap variabel bebas mempunyai korelasi yang linear dengan prestasi hasil belajar matematika.

Tabel 6. Hasil Uji Linearitas

\begin{tabular}{|c|c|c|c|c|c|c|c|}
\hline & & & $\begin{array}{c}\text { Sum of } \\
\text { Squares }\end{array}$ & $D f$ & $\begin{array}{c}\text { Mean } \\
\text { Square }\end{array}$ & $F$ & Sig. \\
\hline Prestasi & Between & (Combined) & 6317,33 & 32 & 197,42 & 0,68 & 0,86 \\
\hline \multirow{8}{*}{$\begin{array}{c}\text { Belajar*Kecerdasan } \\
\text { Emosional }\end{array}$} & Groups & & & & & & \\
\hline & & Linearity & 1391,70 & 1 & 1391,70 & 4,80 & 0,03 \\
\hline & & Deviation & 4925,63 & 31 & 158,89 & 0,55 & 0,95 \\
\hline & & from & & & & & \\
\hline & & Linearity & & & & & \\
\hline & Within & & 10717,18 & 37 & 289,65 & & \\
\hline & Groups & & & & & & \\
\hline & Total & & 17034,51 & 69 & & & \\
\hline \multirow{8}{*}{$\begin{array}{c}\text { Prestasi } \\
\text { Belajar*Kecerdasan } \\
\text { Sosial }\end{array}$} & Between & (Combined) & 9332,33 & 34 & 274,48 & 1,25 & 0,26 \\
\hline & Groups & & & & & & \\
\hline & & Linearity & 513,10 & 1 & 513,10 & 2,33 & 0,14 \\
\hline & & Deviation & 8819,23 & 33 & 267,25 & 1,21 & 0,29 \\
\hline & & $\begin{array}{c}\text { from } \\
\text { Linearity }\end{array}$ & & & & & \\
\hline & Within & & 7702,18 & 35 & 220,06 & & \\
\hline & Groups & & & & & & \\
\hline & Total & & 17034,51 & 69 & & & \\
\hline \multirow{9}{*}{$\begin{array}{c}\text { Prestasi } \\
\text { Belajar*Kemampuan } \\
\text { Awal Matematika }\end{array}$} & Between & (Combined) & 6166,66 & 13 & 474,36 & 2,44 & 0,01 \\
\hline & Groups & & & & & & \\
\hline & & Linearity & 3129,09 & 1 & 3129,09 & 16,12 & 0,00 \\
\hline & & Deviation & 3037,56 & 12 & 253,13 & 1,30 & 0,24 \\
\hline & & from & & & & & \\
\hline & & Lineartly & & & & & \\
\hline & Within & & 10867,85 & 56 & 194,06 & & \\
\hline & Groups & & & & & & \\
\hline & Total & & 17034,51 & 69 & & & \\
\hline
\end{tabular}

\section{Uji Multikolinearitas}

Tujuan dilakukannya uji multikolinearitas agar dapat menunjukkan terdapat korelasi langsung (hubungan) pada variabel bebas terhadap model regresi atau tidak. Jenis model regresi mengharuskan tidak ada permasalahan multikolinearitas. Nilai Variance Inflation Factor (VIF) penelitian ini digunakan pada regresi sehingga dilakukan uji multikolinearitas.

Aturan umum dalam nilai VIF jika lebih besar dari 5 tentunya variabel bebas yang diperoleh memiliki permasalahan multikolinearitas terhadap variabel yang lain. Tabel 7 menunjukkan perolehan nilai VIF pada masing-masing variabel bebas yaitu kecerdasan emosional, kecerdasan sosial, dan kompetensi awal matematika.
Berdasarkan hasil uji linearitas melalui SPSS 21 yang tercantum di tabel 7 menunjukkan nilai VIF pada setiap variabel bebas yakni kecerdasan emosional sebesar 1,78; kecerdasan sosial sebesar 1,82; dan kemampuan awal matematika sebesar 1,04 sehingga tidak terjadi permasalahan multikolinearitas dalam penelitian ini sebab setiap variabel bebas menunjukkan nilai VIF lebih kecil dari 5. 
Tabel 7. Hasil Uji Multikolinearitas

\begin{tabular}{|c|c|c|c|c|c|c|c|c|}
\hline \multirow[t]{2}{*}{ Model } & & \multicolumn{2}{|c|}{$\begin{array}{c}\text { Unstandardized } \\
\text { Coefficients }\end{array}$} & \multirow{2}{*}{$\begin{array}{c}\text { Standardized } \\
\text { Coefficients } \\
\text { Beta }\end{array}$} & \multirow{2}{*}{$\mathrm{t}$} & \multirow{2}{*}{ Sig. } & \multicolumn{2}{|c|}{$\begin{array}{l}\text { Collinearity } \\
\text { Statistics }\end{array}$} \\
\hline & & $B$ & $\begin{array}{l}\text { Std. } \\
\text { Error }\end{array}$ & & & & Tolerance & $V I F$ \\
\hline \multirow[t]{4}{*}{1} & (Constant) & $-31,63$ & 21,85 & & $-1,45$ & 0,15 & & \\
\hline & $\begin{array}{l}\text { Kecerdasan } \\
\text { Emosional }\end{array}$ & 0,50 & 0,23 & 0,30 & 2,20 & 0,03 & 0,56 & 1,78 \\
\hline & $\begin{array}{l}\text { Kecerdasan } \\
\text { Sosial }\end{array}$ & 0,11 & 0,23 & 0,07 & 0,47 & 0,64 & 0,55 & 1,82 \\
\hline & $\begin{array}{l}\text { Kemampuan } \\
\text { Awal } \\
\text { Matematika }\end{array}$ & 0,40 & 0,09 & 0,48 & 4,57 & 0,00 & 0,96 & 1,04 \\
\hline
\end{tabular}

\section{Hasil Analisis Statistik Inferensial}

\section{Uji Hipotesis Secara Simultan}

Dari hasil analisis data melalui uji dalam SPSS 21 seperti di Tabel 9 memperoleh persamaan regresi yakni: $\mathrm{Y}=-31,63+0.50 \mathrm{X}_{1}+0,11 \mathrm{X}_{2}+0,40 \mathrm{X}_{3}$. Dari Tabel 10 terlihat bahwa $p$-value lebih kecil dibanding nilai $\alpha$ yakni $0,00<0,05$ dan dapat disimpulkan adanya korelasi terhadap kecerdasan emosional, kecerdasan sosial, serta kemampuan awal matematika secara bersamaan dan signifikan pada prestasi belajar dalam pelajaran matematika siswa pada SMP Negeri 1 Sungguminasa di kelas VIII.

Tabel 9. Hasil Analisis Regresi Berganda

\begin{tabular}{|c|c|c|c|c|c|c|}
\hline \multirow[t]{2}{*}{ Model } & & \multicolumn{2}{|c|}{$\begin{array}{c}\text { Unstandardized } \\
\text { Coefficients }\end{array}$} & \multirow{2}{*}{$\begin{array}{c}\text { Standardized } \\
\text { Coefficients }\end{array}$} & \multirow[t]{2}{*}{$\mathrm{T}$} & \multirow[t]{2}{*}{ Sig. } \\
\hline & & $B$ & Std. Error & & & \\
\hline \multirow[t]{8}{*}{1} & (Constant) & $-31,628$ & 21,850 & & $-1,448$ & 0,1 \\
\hline & Kecerdasan Emosional & 0,500 & 0,227 & 0,302 & 2,204 & 52 \\
\hline & Kecerdasan Sosial & 0,109 & 0,229 & 0,066 & 0,473 & 0,0 \\
\hline & Kemampuan Awal & 0,401 & 0,088 & 0,479 & 4,574 & 31 \\
\hline & Matematika & & & & & 0,6 \\
\hline & & & & & & 38 \\
\hline & & & & & & 0,0 \\
\hline & & & & & & 00 \\
\hline
\end{tabular}

a. Dependent Variable: Prestasi Belajar

Tabel 10. ANOVA ${ }^{\mathrm{a}}$

\begin{tabular}{c|c|c|c|c|c|c|}
\hline $\begin{array}{c}\text { Mode } \\
l\end{array}$ & & Sum of & Df & Mean Square & $F$ & Sig. \\
\hline 1 & Squares & & & & $0,000^{\mathrm{b}}$ \\
& Regression & 5162,648 & 3 & 1720,833 & 9,567 & \\
& Residual & 11871,863 & 66 & 179,877 & & \\
\hline
\end{tabular}

a. Dependent Variable: Prestasi Belajar

b. Predictors: (Constant), Kemampuan Awal Matematika, Kecerdasan Emosional, Kecerdasan Sosial.

\section{Uji Hipotesis Secara Parsial}

Uji T dilakukan agar bisa menghasilkan variabel bebas dalam kecerdasan emosional, dan kecerdasan sosial, serta kemampuan awal matematika masingmasing berkorelasi terhadap variabel terikat yaitu prestasi hasil belajar pelajaran matematika siswa.

Korelasi antara kecerdasan emosional dalam prestasi belajar matematika siswa
Pada Tabel 9 terlihat bahwa $p$-value kecerdasan emosional lebih kecil dari nilai ayaitu $0,03<0,05$ sehingga terdapat suatu simpulan adanya korelasi positif maupun signifikan kecerdasan emosional sebagai prestasi hasil belajar siswa terhadap pelajaran matematika.

Korelasi antara kecerdasan sosial pada prestasi belajar matematika siswa 
Pada Tabel 9 terlihat bahwa $p$-value kecerdasan sosial lebih besar dari nilai $\alpha$ yaitu $0,638<0,05$ sehingga ditarik suatu kesimpulan tidak terdapatnya korelasi positif maupun signifikan terhadap kecerdasan emosional sebagai prestasi hasil belajar siswa pada matematika.

Korelasi antara kemampuan awal matematika terhadap prestasi belajar matematika siswa

Pada Tabel 9 diperoleh korelasi antara $p$-value kemampuan awal matematika lebih kecil dari nilai $\alpha$ yaitu $0,00<0,05$ sehingga bisa ditarik kesimpulan terdapatnya korelasi positif dan signifikan kompetensi awal matematika bagi prestasi hasil belajar matematika siswa.

\section{Pembahasan}

Korelasi kecerdasan emosional sebagai prestasi belajar matematika siswa

Siswa kelas VIII di SMP Negeri 1 Sungguminasa memiliki tiga kelompok kecerdasan emosional yaitu kategori sedang mencakup 1 siswa sebanyak $1 \%$, kategori tinggi mencakup 29 siswa sebanyak 42\%, dan kategori sangat tinggi mencakup 40 siswa dengan persentase sebesar 57\%. Sementara tidak ada siswa dengan tingkat kecerdasan emosional rendah dan tergolong sangat rendah. Adapun perolehan skor rata-rata dengan kategori sangat tinggi kecerdasan emosional siswa adalah 109,5.

Berdasarkan hasil perolehan analisis data penelitian diperoleh bahwa kecerdasan emosional berkorelasi positif maupun signifikan pada prestasi hasil belajar matematika siswa kelas VIII SMP Negeri 1 Sungguminasa. Hal ini dapat memberikan hasil untuk meningkatkan kecerdasan emosional siswa bisa mendorong siswa untuk upaya dalam meningkatkan prestasi belajar terhadap mata pelajaran matematikanya.

\section{Korelasi antara kecerdasan sosial terhadap} prestasi belajar matematika siswa

Siswa kelas VIII di SMP Negeri 1 Sungguminasa memiliki tiga kelompok kecerdasan sosial yaitu sebanyak 5 siswa kategori sedang memperoleh persentase $7 \%$, sebanyak 31 siswa kategori tinggi memperoleh persentase $45 \%$, serta ada 34 siswa berada kategori sangat tinggi memperoleh persentase $48 \%$. Sementara tidak ada siswa dengan tingkat kecerdasan sosial rendah dan tergolong sangat rendah. Perolehan skor rata-rata kecerdasan sosial siswa adalah 100,4 yang berada di kategori tinggi.

Berdasarkan perolehan hasil analisis data maka kecerdasan sosial tidak berkorelasi positif maupun signifikan pada prestasi siswa di mata pelajaran matematika kelas VIII SMP Negeri 1 Sungguminasa. Dapat diketahui bahwa kecerdasan sosial siswa tidak bisa mendorong siswa di kelas VIII SMP Negeri 1 Sungguminasa dalam peningkatan prestasi belajar matematikanya. Kecerdasan sosial yang dimiliki siswa hanya membantu dalam proses sosialisasi yang baik dengan teman kelasnya tanpa lebih jauh menggunakan pertemanan yang dimilikinya untuk mengembangkan prestasi belajar matematikanya seperti saling belajar satu sama lain.

Pengaruh kemampuan awal matematika terhadap Prestasi Belajar Matematika Siswa

Siswa kelas VIII SMP di Negeri 1 Sungguminasa memiliki lima kelompok tingkat kemampuan awal matematika yaitu tingkatan sangat rendah dan kategori rendah masing-masing sebanyak 11 siswa memperoleh persentase $16 \%$, sebanyak 18 siswa berada di kategori sedang memperoleh persentase $26 \%$, sebanyak 22 siswa berada di kategori tinggi memperoleh persentase $31 \%$, dan sebanyak 8 siswa berada di kategori sangat tinggi melalui persentase $11 \%$. Adapun skor rerata dari keterampilan awal matematika yang berada pada siswa berada dalam kategori sedang sebanyak 69,2.

Berdasarkan perolehan analisis data maka dapat dikatakan bahwa kemampuan awal matematika berkorelasi positif maupun signifikan pada prestasi belajar matematika siswa di kelas VIII SMP Negeri 1 Sungguminasa. Hal tersebut mengemukakan adanya peningkatan kemampuan awal matematika siswa mampu mendorong siswa sebagai upaya peningkatan prestasi belajarnya terhadap pelajaran matematika.

Korelasi antara kecerdasan emosional, kecerdasan sosial, dan kemampuan awal matematika terhadap prestasi belajar matematika siswa

Prestasi hasil belajar siswa terhadap matematika kelas VIII pada SMP Negeri 1 Sungguminasa yang mencakup kategori sangat rendah, rendah, sedang, tinggi, dan sangat tinggi. Terdapat 19 siswa berada di kategori sangat rendah memperoleh persentase $27 \%$, kemudian terdapat 18 siswa memperoleh persentase $26 \%$ atau kategori rendah, terdapat 26 siswa berada dalam kategori sedang melalui persentase $37 \%$, terdapat 6 siswa kategori tinggi melalui persentase $9 \%$, dan sebanyak 1 siswa tergolong pada kategori sangat tinggi yang memperoleh persentase $1 \%$. Adapun skor rata-rata 
prestasi hasil belajar matematika siswa yaitu 61,8 menunjukkan keberadaan dalam kategori rendah.

Berdasarkan perolehan hasil analisis data ditemukan bahwa terdapatnya kecerdasan emosional, sosial, serta kemampuan awal matematika dengan bersamaan berkorelasi positif maupun signifikan pada prestasi hasil belajar matematika dari siswa. Besar korelasi yang diberikan ialah $30 \%$ sementara $70 \%$ lainnya dipengaruhi dari variabel lainnya. Maka ini bisa disimpulkan dengan adanya upaya meningkatkan kecerdasan emosional, dan kecerdasan sosial, serta kemampuan awal pada matematika siswa dapat membantu siswa dalam meningkatkan prestasi belajar matematikanya. Sehingga hal tersebut dianggap penting untuk tiap guru untuk memberikan pemahaman kepada tiap siswa bukan hanya pada kemampuan kognitifnya melainkan pada kecerdasan lainnya terutama kecerdasan emosional dan kecerdasan sosial siswa.

\section{KESIMPULAN}

Berdasarkan hasil analisis dan pembahasan dalam penelitian ini, adapun kesimpulan yang menunjukkan bahwa: (1) Kecerdasan emosional siswa berkorelasi positif maupun signifikan terhadap prestasi hasil belajar siswa dari matematika, (2) Kecerdasan sosial siswa tidak berkorelasi positif maupun signifikan dalam prestasi hasil belajar siswa pada matematika, (3) Kemampuan awal matematika siswa berkorelasi positif dan signifikan pada prestasi hasil belajar matematika siswa, (4) Kecerdasan emosional, dan kecerdasan sosial, serta kemampuan awal siswa pada matematika secara bersama-sama berkorelasi positif maupun signifikan sebagai prestasi belajar siswa dalam matematika kelas VIII di SMP Negeri 1 Sungguminasa.

\section{DAFTAR PUSTAKA}

[1] Dellasera, Qory. 2013. Kualitas Pendidikan Indonesia (Refleksi $2 \quad$ Mei). http://edukasi.kompasiana.com/2013/05/03/ku alitas-pendidikan-indonesia-refleksi-2-mei552591.html). Diakses Pada Tanggal 16 Desember 2014.

[2] Purnama, I. M. Pengaruh kecerdasan emosional dan minat belajar terhadap prestasi belajar Matematika di SMAN Jakarta Selatan. Formatif: Jurnal Ilmiah Pendidikan MIPA, 6(3). 2016.
[3] Chu, Hui-Chun. Potential negative effects of mobile learning on students' learning achievement and cognitive load-A format assessment perspective. Journal of Educational Technology \& Society. 17 (1). 2014.

[4] Depdiknas. Kamus Besar Bahasa Indonesia. Jakarta: Balai Pustaka. 2016.

[5] Siregar, N. R. Persepsi siswa pada pelajaran matematika: studi pendahuluan pada siswa yang menyenangi game. Prosiding Temu Ilmiah Nasional $X$ Ikatan Psikologi Perkembangan Indonesia, 1. 2017.

[6] Gais, Z., \& Afriansyah, E. A. Analisis kemampuan siswa dalam menyelesaikan soal high order thinking ditinjau dari kemampuan awal matematis siswa. Jurnal Pendidikan Matematika, 6(2). 2017.

[7] Lestari, W. Pengaruh kemampuan awal matematika dan motivasi belajar terhadap hasil belajar matematika. Jurnal Analisa, 3(1). 2017.

[8] Eyato, Fatrah D. Pengaruh Kemampuan Awal Matematika, Lingkungan Belajar, dan Kemandirian Belajar Terhadap Hasil Belajar Matematika Siswa SMK Negeri 1 Batudaa Kabupaten Gorontalo. Tesis, tidak dipublikasikan. Universitas Negeri Gorontalo. 2012.

[9] Wahid, Ismi. 2013. Benarkah Kecerdasan Anak Warisan dari Orang Tua?.(http://www.tempo.co/read/news/2013/0 3/17/061467497/Benarkah-Kecerdasan-AnakWarisan-dari-Orang-Tua). Diakses pada tanggal 17 Desember 2014.

[10] Goleman, Daniel. Social Intelligence: The New Science of Human Relationships. Jakarta: PT Gramedia Pustaka Utama. 2006.

[11] Karunianto, A. A. Pengaruh Kecerdasan Sosial Terhadap Prestasi Belajar Siswa Pada Pembelajaran Matematika di MTs Muhammadiyah 1 Malang (Doctoral dissertation, University of Muhammadiyah Malang). 2017.

[12] Jaya, Mulyadi., and Sulaeman. Pengaruh Kecerdasan Emosional Terhadap Kinerja Karyawan Pada Kantoe Kementerian Agama 
Kabupaten Karawang. Jurnal manajemen. 10

(1). 2012.

[13] Goleman, Daniel. Emotional Intelligence. Jakarta: Arga Publishing. 2004.

[14] Albrecht, K. Social Intelligence: The New Science of Success. San Francisco, CA: Jossey-Bass. 2006.

[15] Azwar, S. Penyusunan Skala Psikologis. Yogyakarta: Pustaka pelajar. 2004. 